\title{
Animus toward Muslims and its association with public support for punitive counter- terrorism policies: Did the Christchurch terrorist attack mitigate this association?
}

\section{Objectives}

\section{Abstract}

We apply Unnever and Cullen's (2010) Racial Animus Model to examine support for punitive counter-terrorism policies before and after the 2019 Christchurch terrorist attack.

\section{Methods}

We utilize a natural experiment of survey data from Australians before $(\mathrm{n}=1191)$ and after $(n=1344)$ the attack. Both surveys included a between-groups vignette describing a terrorist as either a right-wing or Islamic extremist. We examined if support for counter-terrorism policies differed between the two conditions and two surveys. We tested whether perceiving Muslims as threatening predicted support for punitive policies, and if the attack mitigated this association.

\section{Results}

Participants were more supportive of punitive policies when a terrorist was motivated by Islamic extremism, but only in the pre-Christchurch sample. Those who perceived Muslims as threatening were more supportive of such policies, but this association was weaker among postChristchurch participants.

\section{Conclusions}

Results support the Racial Animus Model and suggest that empathy might play a role in weakening anti-Muslim animus.

Keywords: punitive attitudes, countering terrorism, racial animus, threat perceptions, Muslims, Christchurch terrorist attack 


\section{Introduction}

Since the 9/11 terrorist attacks in the United States, the pervasive threat of terrorism has spurred the introduction and expansion of a range of preventative and reactive counterterrorism measures by authorities around the world (Roach, 2011). In Western democracies these measures have been criticized because they disproportionately focus on Islamic extremism and consequently, Muslim communities (Breen-Smyth, 2014). However, the recent Christchurch terrorist attack spotlighted the growing threat posed by right-wing extremism (Blackbourn et al., 2019). On 15 ${ }^{\text {th }}$ March 2019, Brenton Tarrant—a 28-year old Australian and self-professed right-wing extremist - entered two mosques in Christchurch, New Zealand, with an arsenal of loaded firearms and began shooting at Muslims attending Friday prayers. The attack killed 51 Muslims, including children, and injured a further 49 (Battersby \& Ball, 2019). The perpetrator live-streamed the event to social media. Tarrant was arrested, pleaded guilty to 92 charges — including one of engaging in a terrorist act — and was sentenced to life in prison without parole. Tarrant's sentencing marked the first terrorism conviction in New Zealand's history.

The Christchurch attack stood in stark contrast to many other large-scale post-9/11 terrorist attacks because it was perpetrated by a right-wing extremist against Muslims (Blackbourn et al., 2019). Despite the fact that other right-wing terrorist attacks have occurred in other parts of the world, public rhetoric still continues to deem Muslims as the predominant terrorist threat in the West (Graham-McLay, 2020). This is concerning because individuals are more likely to express negative, prejudicial or biased attitudes towards individuals they perceive to be a threat (King \& Wheelock, 2007).

Relatedly, criminological research has focused on the predictive power of threat perceptions in shaping public support for punitive crime control policies. Unnever and Cullen (2010) argue that people typically support punitive crime control policies (e.g., the death 
penalty) when those policies are seen to control people or groups perceived to be a safety threat. This reasoning forms the basis of their Racial Animus Model. Reicher and Haslam (2016) recently hypothesized that heightened public support for punitive counter-terrorism policies since $9 / 11$ is partially due to the perceived "Muslim threat." As such, Unnever and Cullen's model can extend to understand how perceptions of Muslims as threatening can shape public support for punitive counter-terrorism policies.

The current study examines whether public support for punitive counter-terrorism policies in Australia is associated with perceiving Muslims as a threat. Further, the current study also explores whether public support for punitive counter-terrorism measures differed among two samples of Australian participants before and after the Christchurch attack. As noted above, the Christchurch attack differed from many recent terrorist attacks because they highlighted that terrorists are not always Muslim, and that victims of terrorism can be Muslim. Evidence testing the impact of a terrorist attack on public sentiment is extremely rare. As such, data collected before and after a terrorist attack can be useful for exploring how such an event might alter public sentiment toward certain groups or crime control policies (Van de Vyver et al., 2016).

Prior to outlining the methodology of the current study, the next section first discusses the counter-terrorism landscape in Australia, before overviewing the criminology literature linking racial animus with public support for punitive crime control policies. This will be followed by a discussion of how empathy may serve as a possible psychological mechanism that mitigates the association between racial animus and support for punitive crime-control policies.

\section{Counterterrorism and Muslim communities in Australia}

Since 9/11, a vast range of counter-terrorism laws have been introduced and expanded across Australia and other western countries (Roach, 2011). These laws are often described as 
punitive because they afford authorities exclusive powers of surveillance, detention and interrogation (Lynch et al., 2015). In Australia alone, new legislation continues to be passed, expanding the already extensive suite of over 80 counter-terrorism laws (McGarrity \& Blackbourn, 2019).

The expansive nature of counter-terrorism policies and legislation introduced in Australia and other western nations (e.g., the US or UK) have consequences for Muslim communities living in those countries. For example, the ability of counter-terrorism policies to criminalize preparatory offences, sometimes without proof of criminal intent, sees their use by police being disproportionately applied to certain groups. For example, authorities often conflate Islam with terrorism (Sentas, 2014). Resultantly, Muslim populations come under suspicion more often by authorities (Sentas, 2014). Simultaneously, some Muslims report that they feel disproportionately targeted and scrutinized because of these laws (Cherney \& Murphy, 2016). In two recent Australian studies, Muslim interview participants described feeling under scrutiny because such counter-terrorism policies seemingly "clamped down mostly on [their] community" (Bull \& Rane, 2019, p. 285; see also Cherney \& Murphy, 2016).

Unfortunately, within Australia, those identifying as Muslim have committed the majority of terrorist attacks (Zammit, 2017). This fact has perpetuated the view among the public and authorities that Islam is a violent religion and that Muslims are a group to be feared. Terrorism laws are therefore applied more frequently to Muslim defendants in Australia. Additionally, the media and governments in Australia and elsewhere continue to state that there is a persistent threat of Islamic extremism to global security (Williamson et al., 2019). This notion is reinforced by governmental responses such as the proscription regime, whereby to date only terrorist organizations with an Islamic ideology have been proscribed as terrorist organizations by the Australian Government (Lynch, et al., 2015). 
Moreover, the combination of national security and immigration legislation (e.g., citizenship stripping) in Australia's counter-terrorism framework further defines the groups who should be deemed the greatest threat (Crocker et al., 2007). Specifically, the securitization of migration as a national security measure arguably reinforces stereotypes that stigmatize certain minority groups perceived to be outsiders, as highlighted in other contexts including Canada (Faist, 2002) and Europe (Robin-Olivier, 2005). In this sense, those from a Muslim background can be scrutinized more heavily under the guise of preserving national security.

\section{Racial Animus, Perceptions of Threat, and Support for Punitive Punishment Policy}

The broader nature of punishment can be shaped by perceptions that certain groups are more threatening than others (King \& Wheelock, 2007). Research shows that support for punitive crime control policies correlate strongly with people's heightened perceptions of threat regarding particular groups in the population (Unnever \& Cullen, 2012). Scholars often argue that crime is racially typified, such that members of racial minority groups are perceived as more likely to be involved in criminal activity (e.g., Jacobs \& Carmichael, 2002).

Underpinning the notion that perceived threat and intolerance of racial minority groups shapes punitive attitudes toward punishing those groups is the Racial Animus Model (Unnever \& Cullen, 2010). This model posits that when individuals harbor negative evaluations of racial minority groups and perceive them as threatening, they are more likely to support punitive crime control policies they believe will control such "threatening" groups. The model draws from two prominent theoretical frameworks: the Minority Threat Thesis and the Racial Typification of Crime Framework (Blumer, 1958; King \& Wheelock, 2007). The Minority Threat Thesis links racial prejudice with increased group-based social control towards minority groups (Blumer, 1958). In a similar vein, the Racial Typification of Crime Framework is centered around denoting racial out-group members as the "other" and 
connecting the notion of the "other" with criminality (Unnever \& Cullen, 2010). These beliefs subsequently enhance attitudes in favor of punitive crime control policies that control and punish groups perceived as a criminal threat.

Before developing the model, Unnever et al. (2008) noted how Caucasian Americans were more likely than African Americans to support the death penalty. They noted that this racial divide has persisted for decades and remains even after controlling for known correlates of death penalty attitudes. Unnever et al. (2008) suggested that a significant explanation for this difference is racism, "with whites who manifest animus to blacks being more likely to embrace the lethal punishment of offenders" (p.45). They argue that this occurs because people of color are perceived to be a 'criminal threat' by Caucasians and the death penalty is a means of controlling the perceived threat. Such threat-based theories further suggest that punitive policies provide Caucasian people with a means to control or subjugate minority groups, and a way for Caucasian people to vent anti-minority sentiments (Jacobs \& Carmichael, 2002).

The association between perceiving racial minority groups as a criminal threat and support for punitive punishments of those groups has received strong empirical support in the general crime control literature (see e.g., Chiricos et al., 2004; Unnever \& Cullen, 2010). However, scant research exists in the counter-terrorism context (for exceptions see Piazza, 2015; Welch, 2016; Williamson, 2019). We are aware of only two published studies that have directly identified a positive relationship between perceiving Muslims as a threat and subsequent support for punitive counter-terrorism policies.

Welch (2016) drew on survey data from 425 adults residing in America to determine if linking individuals of Middle Eastern descent with terrorism predicted support for punitive counter-terrorism policies. Welch revealed that support for punitive counter-terrorism policies was stronger among those who stereotyped Middle Eastern individuals as terrorists. 
More recently, Williamson (2019) utilized survey data from a sample of 1,199 non-Muslim Australians. Williamson (2019) showed that participants who perceived Muslims as a greater threat were more likely to support punitive counter-terrorism policies. While not directly linking threat attitudes to support for punitive counter-terrorism policies, Piazza (2015) drew on a sample of 1,135 individuals in the United States to compare the public's views of a Muslim or non-Muslim hypothetical terror suspect. Piazza (2015) aimed to discern differences in punitive sentiment towards the use of interrogation and detention techniques for different terrorist suspects. Using an experimental vignette design, Piazza (2015) manipulated the religious affiliation of a terrorism suspect. Piazza (2015) found that greater public support for punitive interrogation and detention measures was found when the suspected terrorist was described as being Muslim. Other studies similarly find that perceiving Muslims as a threat can increase public support for measures such as banning headscarves (van der Noll, 2010), and restricting civil liberties (Nisbet et al., 2008). Together, these aforementioned studies suggest an association between perceiving Muslims as threatening and support for punitive counter-terrorism policies. Terrorism events provide a rationale for governments to amend legislation or introduce new and harsher counterterrorism laws in response (Williams, 2011). The occurrence of these events may also significantly impact public support for punitive counter-terrorism policies. Yet, few empirical studies exist that examine public attitudes before and after a significant terrorist attack. Those few studies that do exist focus exclusively on Islamic extremism and show that anti-Muslim sentiment typically increases after such attacks (e.g., Abrams et al., 2017; Van de Vyver et al., 2016). To date, no study has examined whether public support for punitive counterterrorism measures differs before and after a right-wing terrorist attack perpetrated against members of the Muslim community. The current study is the first to do so.

\section{The role of empathy in mitigating racial animus after a terrorist attack}


The Racial Animus Model might explain how and why perceiving Muslims as a threat is associated with greater support for punitive counter-terrorism policies. However, it offers little in the way of explaining how or why public support for punitive counter-terrorism policies might change after a terrorist attack. We thus draw on research linking empathy to punitive sentiment to explain how wider public sentiment following a right-wing terrorist attack such as the Christchurch attack might alter the association between perceiving Muslims as threatening and support for counter-terrorism policies.

Empathy occurs when a person sympathizes with an individual's pain and suffering and has an emotional reaction to the other's distressing situation (Unnever \& Cullen, 2009). Empathizing with the suffering of others can change individuals' perspectives on various matters (Unnever, et al., 2005). For example, empathy has been shown to reduce the psychological distance a prejudiced person places between themselves and the target of their prejudice (Finlay \& Stephan, 2000). Empathy also enables an individual to identify with certain groups (e.g., African Americans convicted of street crime; see Unnever \& Cullen, 2009). Batson et al. (1997) argue that there is a three-stage process by which attitudes change in response to empathy. First, people experience empathic concern for an individual who is suffering. Second, empathizing with suffering individuals leads people to value the welfare of the victim. Third, concern for the welfare of the person generalizes to the group to which this person is a member.

We propose that empathy towards Muslims after the Christchurch attack might explain positive change in sentiment regarding counter-terrorism policies after the attack. Support for such an assertion comes from the following studies. Finlay and Stephan (2000) asked Caucasian Americans to read a series of vignettes written by African Americans that depicted everyday acts of discrimination directed toward them (including being perceived as a threat simply because of their race). The vignettes contained reports of the victims' feelings 
about these acts of discrimination. One group of participants was asked to imagine how the person in the vignette would feel and to try and identify with their feelings and responses. A second group of participants received no such instructions to empathize with the victim. Findings showed that differences between participants' evaluations of African Americans and Caucasians disappeared for those who were instructed to empathize with African American victims. In contrast, those in the control condition held more negative evaluations of African Americans.

Of most relevance to the current study, Unnever et al. (2005) also contend that empathy for others can mitigate support for punitive crime control policies because it can reduce racial animus. Using survey data, Unnever et al. (2005) showed that Americans who harbored more racial and ethnic intolerance were significantly more likely to support capital punishment. Their study also found that empathy for certain groups indirectly reduced support for capital punishment by decreasing racial and ethnic prejudices. Importantly, Unnever et al. (2005, p. 23) suggested an area of research needing further exploration is whether empathy might predict opposition to punitive crime control policies in contexts other than capital punishment. We respond to Unnever et al.'s suggestion to consider the role of empathy in crime control contexts other than capital punishment.

\section{The Current Study}

The current study draws on Unnever and Cullen's (2010) Racial Animus Model to understand how public support for punitive counter-terrorism policies may be associated with perceiving Muslims as threatening. It draws on a natural experiment to explore how this association changes over time by: (a) comparing survey data collected before and after the Christchurch terrorist attack from two national samples of the Australian population; and (b) using an embedded between-groups vignette experiment in both surveys, where the motivation of a terrorist suspect is manipulated (Islamic extremist vs right-wing extremist). 
Given the outpouring of support offered to Muslim communities around the world in the aftermath of the Christchurch attack, we suggest that the attack may have led many nonMuslims to feel empathy for the Christchurch victims and Muslims more generally. As such, we propose that the event will mitigate the positive association between perceiving Muslims as threatening and support for punitive counter-terrorism policies among participants in the post-Christchurch survey. Based on the tenets of the Racial Animus Model and empathy research cited above, we expect:

1. Participants will be more likely to support punitive counter-terrorism policies if a terrorist is portrayed as an Islamic extremist compared to a right-wing extremist prior to the Christchurch attack, but not after the attack (Hypothesis 1);

2. A positive association will exist between perceiving Muslims as a terrorist threat and support for punitive counter-terrorism policies (Hypothesis 2);

3. The association between perceiving Muslims as a terrorist threat and support for punitive counter-terrorism policies will be weaker following the Christchurch attack (Hypothesis 3).

While we do not directly test the role of empathy in the current study, we draw upon research and theorizing to posit how and why animus towards Muslims and support for punitive counter-terrorism policies might change in the aftermath of a right-wing terrorist attack perpetrated against Muslims. As such we propose that the association between perceiving Muslims as threatening and support for punitive counter-terrorism policies may be weaker following the Christchurch attack because Australians empathized more with Muslims after the attack.

\section{Methods}

\section{Participants and procedure}


The current study is situated in Australia. Australia is widely acknowledged as being a tolerant and multicultural society, with residents originating from all corners of the globe. Australia's most recent census reveals that Muslims constitute about $2.6 \%$ of the Australian population (Australian Bureau of Statistics, 2016). The data used for this study were drawn from two national cross-sectional surveys, fielded one year before and one month after the 2019 Christchurch terrorist attack. Both surveys were fielded on Facebook for four weeks (see Williamson, Murphy, \& Sargeant, 2018).

A total of 1,423 participants completed the pre-Christchurch survey. Following a missing data analysis, 224 were discarded from the sample. Eight additional cases were removed because these participants identified as Muslim. This left 1,191 useable surveys. Over half of the final sample were females (57.2\%) and participants' average age was 37.2 years old $(\mathrm{SD}=14.42)$. The majority of participants were Australian born $(84.3 \%)$.

The post-Christchurch survey was completed by 1,634 participants. A missing data analysis was conducted, and 279 cases were removed. A further 11 cases were removed because these participants identified as Muslim, resulting in a final sample size of 1,344 respondents. Half of the sample were female (50.0\%), and participants' average age was slightly higher than in the pre-Christchurch survey $(\mathrm{M}=44.7, \mathrm{SD}=15.3)$. Again, most participants were Australian born (81.1\%). Table 1 presents the sample representativeness of participants who completed both surveys against Australian Census figures. As can be seen from Table 1, both survey samples were broadly representative of the overall Australian population.

[Table 1]

\section{Measurement construction}

Vignette manipulation. Contained in both the pre- and post-Christchurch surveys was a between-groups experiment whereby a vignette scenario depicted a hypothetical food 
tampering terrorist incident at a number of fast-food restaurants. The vignette highlighted that numerous people had collapsed and been taken to hospital, insinuating they had been poisoned. Importantly, the vignette manipulated the motivation of the terrorist perpetrator in the scenario (i.e., motivated by Islamic extremism or by far-right extremism). Vignette A outlined that the perpetrator published a post on a radical Muslim Facebook page and described their willingness to take action in the name of Allah. Vignette B outlined that the perpetrator published a post on a right-wing extremist Facebook page and described their willingness to take action in support of the anti-immigration movement. Survey participants were randomly assigned to receive one of the two vignettes. The Appendix presents the exact wording of the two vignette scenarios.

After reading their respective vignette, participants answered numerous multi-item scales. For the current paper, two key scales were of interest: (1) perceptions that Muslims are threatening, and (2) support for punitive counter-terrorism policies (Table 2 overviews the wording of items used in each scale). The construct validity of the two scales was determined using Principal Components Analysis with varimax rotation. Results of this analysis revealed two distinct components (see Table 2).

[Table 2]

Perceptions that Muslims are threatening. A seven-item scale adapted from the work of Velasco González et al. (2008) measured the extent to which participants perceive Muslims as threatening. Each item asked participants to rate on a five-point Likert scale $(1=$ strongly disagree to $5=$ strongly agree) their level of agreement towards perceptions of Muslims as a safety and wellbeing threat, a threat to Australian values and way of life, and as a terrorist threat. Participants who scored higher on this mean-constructed scale perceive Muslims as more threatening $(\mathrm{M}=2.31, \mathrm{SD}=1.20$, alpha $=0.97)$. 
Support for Punitive Counter-terrorism policies. This scale includes eight items adapted from the work of Welch (2016). Each item measures the extent to which participants approved of punitive Australian policies to prevent and counter terrorism. Each item asked participants to rate on a five-point Likert scale ( $1=$ strongly disapprove to $5=$ strongly approve $)$ their level of approval with each policy, such as 'the ability to detain terrorism suspects for up to 48 hours without charge' (see Table 2). A higher score on the mean-constructed scale indicates stronger approval of punitive counter-terrorism policies $(\mathrm{M}=3.13, \mathrm{SD}=0.99$, alpha $=0.90)$.

Control variables. Previous research on support for punitive crime control policies often finds demographic differences predict support (Welch, 2016). Thus, we included the following demographic variables to discern potential differences in support for punitive counter-terrorism policies: age $(\mathrm{M}=41.2 ; \mathrm{SD}=15.24)$; gender $(0=$ female; $1=$ male $)$; country of birth ( 0 = overseas born; 1 = Australian born); educational attainment (ranging from $1=$ did not complete high school to $6=$ postgraduate qualifications) and employment status $(0=$ not employed; $1=$ employed $)$. Previous research also highlights that punitive attitudes towards crime control policies are stronger among individuals who hold more rightwing, conservative or nationalistic views (Chiricos et al., 2004; Welch, 2016). Hence, a political orientation measure was also used as a control variable. Participants were asked to rank how 'left' ('liberal') or 'right' ('conservative') leaning they were on a scale from 1 to 10 $(1=$ more left leaning to $10=$ more right leaning $)$. Finally, to determine potential differences in attitudes before and after the Christchurch attack, a between-groups dummy variable for survey time was constructed to control for when survey data was collected $(0=$ preChristchurch; 1=post-Christchurch). Table 3 outlines the descriptive statistics for the two key scales, and demographic and control variables, as well as the bivariate relationships between measures. 
[Table 3]

\section{Results}

\section{ANOVA and t-tests}

To address Hypothesis 1, we first conducted a 2x2 between-groups ANOVA and a series of independent samples t-tests with support for punitive counter-terrorism policies as the dependent variable. The ANOVA examined if the vignette manipulation (Islamic extremist vs right-wing extremist) and survey time (pre-Christchurch vs post-Christchurch) had an effect on support for punitive counter-terrorism policies. The vignette manipulation effect was significant. Overall, the findings revealed that participants who received the Islamic extremist scenario were significantly more likely to support punitive counterterrorism policies than those who received the right-wing extremist scenario $(\mathrm{F}(1$, $2104)=6.20, \mathrm{p}<0.05$ ). Additionally, the survey time effect was also significant. Participants who completed the post-Christchurch survey were more likely to support punitive counterterrorism policies than those who completed the pre-Christchurch survey $(F(1,2104)=6.76$, $\mathrm{p}<0.01)$.

To explore these effects further, we conducted a series of independent samples t-tests comparing mean scores on support for counter-terrorism policies across the four conditions (see Figure 1). Considering the results from the pre-Christchurch survey first, we found that participants who received the Islamic extremist vignette $(\mathrm{M}=3.17, \mathrm{SD}=1.00, \mathrm{n}=502)$ were significantly more likely to support punitive counter-terrorism policies when compared to those who received the right-wing extremist vignette $(\mathrm{M}=3.00, \mathrm{SD}=0.99, \mathrm{n}=487 ; \mathrm{t}(987)=-$ $2.83, \mathrm{p}<0.01)$. For participants who completed the post-Christchurch survey, in contrast, there was no statistical difference in support for terrorism policies between those who received the Islamic extremist scenario $(\mathrm{M}=3.22, \mathrm{SD}=1.00, \mathrm{n}=578)$ compared to those who received the right-wing extremist scenario $(\mathrm{M}=3.18, \mathrm{SD}=0.96, \mathrm{n}=554 ; \mathrm{t}(1130)=0.69, \mathrm{p}>0.05)$. 
Further inspection of Figure 1 suggests that survey participants who received the right-wing extremist scenario became more supportive of punitive counter-terrorism policies after the Christchurch attack, but there was little difference between the pre- and postsurveys in support for punitive policies for those receiving the Islamic extremist scenario. Two further t-tests confirmed this. For those receiving the Islamic extremist scenario, mean scores were compared between the pre-Christchurch $(\mathrm{M}=3.17, \mathrm{SD}=1.00, \mathrm{n}=502)$ and postChristchurch surveys $(\mathrm{M}=3.22, \mathrm{SD}=1.00, \mathrm{n}=578)$. There was no statistical difference between the mean scores $(\mathrm{t}(1078)=-0.82, \mathrm{p}>0.05)$. However, when comparing the pre-Christchurch survey results $(M=3.00, S D=0.99, n=487)$ to the post-Christchurch survey results $(M=3.18$, $\mathrm{SD}=0.96, \mathrm{n}=554$ ) for those receiving the far-right extremist scenario, findings revealed a significant difference between support for counter-terrorism policies $(\mathrm{t}(1039)=-2.97, \mathrm{p}<0.01)$. Here, support for punitive counter-terrorism policies was significantly higher after the Christchurch attack for those receiving the right-wing scenario.

Together, these findings lend support to Hypothesis 1; specifically, the Australian public supported punitive counter-terrorism policies more when a terrorist was portrayed as an Islamic extremist prior to the Christchurch attack, but not among participants surveyed after the attack. Rather, the Christchurch attack seemed to highlight that terrorists can be nonMuslim, resulting in an increase in punitive attitudes toward right-wing extremists and towards terrorism more generally.

\section{[Figure 1]}

\section{Regression}

The vignette experiment was unable to directly test the association between 'perceiving Muslims as a threat' and subsequent support for punitive counter-terrorism policies. To address Hypotheses 2 and 3, therefore, we undertook an Ordinary Least Squares (OLS) regression analysis to test if there was an association between perceiving that Muslims 
are threatening and support for punitive counter-terrorism policies (see Table 4). Variables were entered in blocks to determine the variance each block of variables contributed to the dependent variable. In Block 1 , the vignette manipulation variable $(0=$ right-wing extremist; 1=Islamic extremist) was entered. In Block 2, demographic variables, political orientation and survey time (pre-Christchurch; 1=post-Christchurch) were added. In Block 3, the perceptions that Muslims are threatening scale was entered. Finally, in Block 4, a two-way interaction between survey time and perceptions that Muslims are threatening was included. All continuous variables were mean centered before being entered into the model.

The vignette manipulation variable entered in Block 1 was significant but accounted for less than $1 \%$ of the variance in support for punitive counter-terrorism policies. The effect suggests that participants who received the Islamic extremist scenario were more supportive overall of punitive counter-terrorism policies $(\beta=0.052, \mathrm{p}<0.05)$. However, this effect disappeared after the addition of other variables in Block 2. Of the variables entered into Block 2, political orientation $(\beta=0.465, \mathrm{p}<0.001)$ was most strongly and positively associated with support for punitive counter-terrorism policies. Not surprisingly, conservative (i.e., right-leaning) participants were more supportive of punitive counter-terrorism policies. Age $(\beta=0.151, \mathrm{p}<0.001)$ and gender $(\beta=0.178, \mathrm{p}<0.001)$ were also positively and significantly associated with support for punitive counter-terrorism policies, with older participants and females being more supportive of punitive counter-terrorism policies. Those who reported higher educational attainment were less likely to support such policies $(\beta=$ $0.180, \mathrm{p}<0.001)$.

In Block $3\left(\mathrm{R}^{2}\right.$ change $\left.=0.119\right)$, the perceptions that Muslims are threatening scale was entered. Results show that participants who perceived Muslims to be a greater threat were more likely to support punitive counter-terrorism policies $(\beta=0.447, \mathrm{p}<0.001)$. This particular finding supports Hypothesis 2 . With the exception of gender $(\beta=0.196, p<0.001)$, 
the strength of the association between the other control variables and the dependent variable reduced substantially when the perceptions of threat scale was added into the model.

[Table 4]

In the final block of the regression, a 'survey time' $\mathrm{x}$ 'perceptions that Muslims are threatening' interaction term was entered. The interaction effect was negative and significant $(\beta=-0.177, p<0.01)$. Figure 2 presents the interaction effect graphically. To examine the interaction effect further, simple slope tests were computed at -1 (low) and +1 (high) standard deviations of the Muslims are threatening scale. The simple effects tests reveal that the association between perceiving Muslims as threatening and support for punitive counterterrorism policies was stronger prior to the Christchurch attack $(\beta=0.561, \mathrm{p}<0.001)$ than after the Christchurch attack $(\beta=0.470, \mathrm{p}<0.001)$. These results support Hypothesis 3 and suggest that the association between animus and support for punitive counter-terrorism policies was weaker among Australians who were surveyed following the Christchurch attack.

[Figure 2]

\section{Discussion and Implications}

This study tested the applicability of Unnever and Cullen's (2010) Racial Animus Model in the counter-terrorism context. Specifically, it examined whether public support for punitive counter-terrorism policies is associated with animus toward Muslims (i.e., perceiving Muslims as a threat). It did so by testing whether Australians would provide greater support to punitive counter-terrorism policies when presented with a vignette describing a terrorism suspect as an Islamic extremist compared to a right-wing extremist.

We also utilized a natural experiment to examine the association between perceiving Muslims as threatening and support for counter-terrorism policies before and after the Christchurch attack using two national samples of the Australian population. As highlighted 
in the introduction, the Christchurch attack was unique in that it was a terrorist attack perpetrated by a right-wing extremist against Muslim victims.

Findings from the between-groups vignette study highlighted that prior to the Christchurch attack, Australians were more likely to support punitive counter-terrorism policies when they received a vignette portraying an Islamic extremist compared to a rightwing extremist. Importantly, this difference was absent among participants surveyed after the Christchurch attack. However, this vignette experiment was unable to directly test the association between perceiving Muslims as threatening and support for punitive counterterrorism policies. To explore this association, we conducted a regression and included a number of factors known to predict support for punitive crime control policies. We found that perceiving Muslims as threatening was the strongest predictor of public support for punitive counter-terrorism policies; participants who viewed Muslims as more threatening were more likely to support punitive counter-terrorism measures. Importantly, the relationship between perceiving Muslims as threatening and support for punitive counter-terrorism policies changed after the Christchurch attack. An interaction effect revealed that the strength of the association between the two variables was weaker among participants surveyed after the Christchurch attack.

Taken together, our findings support Unnever and Cullen's (2010) Racial Animus Model and confirm its relevance in the counter-terrorism context. Stereotypes and prejudices often directed towards minority groups perceived as criminals can explain how non-Muslims can come to support punitive counter-terrorism policies when they regard Muslims as suspects or terrorists (Chiricos et al., 2004; Unnever \& Cullen, 2010, 2012). Unnever and Cullen (2010) suggest this is so because when individuals harbor negative evaluations of minority groups (e.g., Muslims) and perceive them as threatening, they are more likely to support punitive crime control policies they believe will control such "threatening" groups. 
By examining non-Muslims' attitudes towards Muslims, who are a minority group characterized primarily by their religion, this study extends the existing application of Unnever and Cullen's (2010) Racial Animus Model to consider terrorism as a type of crime, and religion as a defining out-group feature. Our findings demonstrate that it is not just racial and ethnic animus, but also religious animus that can shape support for punitive counterterrorism policies (c.f. Williamson, 2019).

Our study further extended prior research by investigating how a right-wing terrorist event appeared to alter the association between perceiving Muslims as a threat and support for punitive counter-terrorism policies. We used survey data collected both before and after a self-professed right-wing extremist deliberately targeted Muslims attending Friday prayer in Christchurch, New Zealand. By exploring the interaction between perceptions of threat and support for punitive counter-terrorism policies before and after the Christchurch attack, this study demonstrated that the attack may have mitigated the association between perceiving Muslims as a threat and support for punitive counter-terrorism policies. While we did not directly measure empathy in explaining this change, our finding points to the possible explanatory value of empathy in changing attitudes after a terrorist event.

Prior research suggests that empathy can reduce support for punitive policies by decreasing the prevalence of prejudice felt towards minority groups (Unnever et al., 2005). Moreover, prior research shows that individuals who feel empathy toward minority groups harbor less prejudices towards those groups because they sympathize with minority groups' experiences of prejudice and resultantly hold more positive evaluations of such groups (Stephan \& Finlay, 1999). The Christchurch attack challenged the widespread view that Muslims pose an exclusive terrorist threat. Specifically, the attack emphasized that terrorists are not always Muslim and that counter-terrorism measures are not exclusively applied to Muslims. Our findings suggest that this recognition may have tempered the association 
between perceiving Muslims as threatening and support for punitive counter terrorism measures. We propose this may have worked by eliciting public empathy toward Muslim communities after the attack, which in turn reduced prejudice toward Muslims and perceptions that Muslims pose a threat to the general public. While it is important to reiterate that we did not directly test the role of empathy and as such our discussion here is speculative, our findings do suggest that public support for punitive counter-terrorism policies can be context-dependent.

Our findings also have implications for public policy. They highlight the need to challenge harmful views regarding Muslims, to dispel the myth that Muslims are intrinsically linked to terrorism, and to find ways to elicit the public's empathy for Muslims' experiences of vilification. This is often difficult to do, however, when media discourses and political rhetoric often undo any efforts to contest this harmful link (Powell, 2011). Following the 2019 Christchurch terrorist attack, Australia’s Prime Minister Scott Morrison expressed sympathy for the victims of the attack. He also strongly condemned the actions of the Australian right-wing perpetrator. Yet, his words were quickly overshadowed by references made in the media to his previous speeches, which contained inflammatory statements linking Muslims with terrorism (Tingle, 2019). A conservative Australian politician-Senator Fraser Anning - also openly blamed the Christchurch attack on Muslims themselves (Baker, 2019). Such statements and media reporting can reinforce the public's view that Muslims pose a threat to public safety. It is therefore necessary not only to challenge biased depictions of Muslims but to emphasize and encourage accurate portrayals of Muslims by politicians and the media (Williamson et al., 2019). Counter-narratives may be relevant here.

Counter-narratives are often utilized to prevent radicalization through empowering atrisk individuals to question the legitimacy of terrorist narratives and "challeng[e] the themes that underpin terrorist messages" (Braddock \& Morrison, 2020, p. 469). There is some 
evidence that they can be successful in preventing radicalization (Braddock \& Horgan, 2016). Counter-narratives may also be useful in political rhetoric to ensure that politicians' discussions about terrorism and radicalization are balanced and do not disproportionately focus on Muslim communities. Specifically, such counter narratives could challenge and reframe the dominant narrative that Muslims pose a threat and that Islam is a violent religion. Doing so may reduce prejudicial thinking among the mainstream population and foster social cohesion and intergroup harmony (Williamson, 2019). Moreover, the use of such counter narratives may also reduce support for far-right ideals. However, the efficacy of counternarratives hinges on ensuring that the content is trustworthy and the source is perceived as credible and legitimate (Braddock \& Horgan, 2016). As such, ensuring that authorities have guidelines to effectively disseminate counter-narratives that do not perpetuate anti-Muslim animus and prejudices more broadly is critical to their success and reception. Given the history of contradictory statements made by Australian politicians about Islamic extremism and Muslims more generally, ensuring effective guidelines to construct and publish counternarratives is especially crucial.

Findings from our study also point to a need to ensure counter-terrorism policies do not alienate the very groups that we rely on to address terrorism. Spalek and Imtoual (2007) argue that counter-terrorism policies have conflicting objectives whereby they are used disproportionately against Muslim communities but simultaneously rely on such communities to help authorities to counter terrorism (see also Cherney \& Murphy, 2016; Huq, Tyler \& Schulhofer, 2011; Jonathan-Zamir \& Weisburd, 2013; Murphy, Madon, \& Cherney, 2020). The motives behind the Christchurch attack also reinforce the notion that terrorism is not just an issue concerning Muslims, despite the primary focus on Muslims and Islamic extremism in political and media discourses. As such, ensuring that counter-terrorism policies and associated discussions about terrorism are balanced and reflect the contemporary terrorism 
threat is crucial when their introduction and continued use are influenced by public support for such policies (Lynch et al., 2015).

\section{Study limitations}

While the current study revealed the applicability of Unnever and Cullen's (2010) Racial Animus Model to understand public support for punitive counter-terrorism measures and offered implications for public policy, we should acknowledge the limitations in our research that need to be considered when interpreting the findings. First, we drew on data from two cross-sectional surveys. While the vignette experiment did show that survey participants were more likely to support punitive counter-terrorism measures when presented with an Islamic terrorist scenario prior to the Christchurch attack but not after them, we cannot ascertain definitively whether this change in support for counter-terrorism policy was due directly to the Christchurch attack. Longitudinal panel survey data is ideal, but difficulties in predicting when a terrorist attack will occur presents a challenge in fielding surveys at appropriate times. This is why the few studies that examine attitude changes before and after terrorist attacks tend to rely on surveys of different participants (e.g., Abrams et al., 2017; van de Vyver et al., 2016).

Second, the sample used in both surveys was broadly representative of the Australian population but there were some minor differences in the samples when compared to Australian population characteristics. This limits the ability to make generalizations to all Australians. For example, highly educated respondents were more likely to participate in our research. Previous research shows that increases in education are associated with lower support for punitive crime control policies (Welch, 2016). As such, we likely skewed our sample to those who opposed punitive counter-terrorism policies. Whether our results can be replicated with a truly representative and panel sample remains to be seen. 
Third, the nature of our vignette may have impacted participants' responses. The vignette described a food tampering incident, which, while utilized in other terrorism research (Nolan, 2008), does depict a less violent form of terrorism. Many recent terrorist events have used knives, guns or vehicles to injure or kill victims. It is conceivable that had our vignette described a more severe terrorist scenario, study participants may have responded differently to questions asking about support for counter-terrorism policies. Future research may wish to replicate our findings using a different hypothetical terrorist scenario.

Finally, we posited that empathy towards Muslims would be heightened in the aftermath of the Christchurch attack. We suggested this would reduce the strength of the association between perceiving Muslims as threatening and support for punitive counterterrorism measures. Our results certainly point to this possibility. However, we did not explicitly measure and test empathy and its relationship to the key variables of interest. So, while empathy seems a plausible theoretical explanation for the findings, future research must confirm this empirically.

\section{Conclusion}

Despite these limitations, our study provided support for Unnever and Cullen's (2010) Racial Animus Model and demonstrated its applicability to the counter-terrorism context. Specifically, perceiving Muslims as threatening was related to public support for punitive counter-terrorism measures. Importantly, our study revealed that the Christchurch terrorist attack mitigated the association between these two variables. That is, the strength of the association between perceiving Muslims as threatening and support for punitive counterterrorism measures was weaker among participants surveyed following the terrorist attack when compared to those surveyed before the attack. We suggested that the Christchurch attack highlighted the fact that Muslims can be victims of terrorism, and non-Muslims can perpetrate terrorism. As such, we argued that a possible psychological mechanism 
responsible for the weakening of the animus effect post-Christchurch was empathy for Muslims. As noted earlier, Batson et al. (1997) suggest that attitudes toward minority groups can change in response to people feeling empathy for those individuals because empathy for individuals can generalize to the broader social group to which that person is a member. Our research therefore highlights how prejudice towards Muslims can play a prominent role in shaping public support for punitive and reactive legislative responses to terrorism. To mitigate this relationship, it is important for governments to limit their anti-Muslim rhetoric, ensure that counter-terrorism legislation does not disproportionately single out Muslim community members, and find ways to promote public empathy for Muslim communities. 


\section{References}

Abrams, D., Van de Vyver, J., Houston, D. M., Vasiljevic, M. (2017). Does terror defeat contact? Intergroup contact and prejudice toward Muslims before and after the London bombings. Peace and Conflict: Journal of Peace Psychology, 23(3), 260-268.

Australian Bureau of Statistics. (2016). 2016 Census. http://www.abs.gov.au/websitedbs/censushome.nsf/home/2016

Baker, N. (2019). Outrage as Fraser Anning blames NZ attacks on 'Muslim immigration'. SBS News. https://www.sbs.com.au/news/outrage-as-fraser-anning-blames-nz-attacks-onmuslim-immigration

Batson, C. D., Polycarpou, M. P., Harmon-Jones, E., Imhoff, H. J., Mitchener, E. C., Bednar, L. L., Klein, T. R., \& Highberger, L. (1997). Empathy and attitudes: Can feeling for a member of a stigmatized group improve feelings toward the group? Journal of personality and social psychology, 72(1), 105.

Battersby, J., \& Ball, R. (2019). Christchurch in the context of New Zealand terrorism and right-wing extremism. Journal of policing, intelligence and counter terrorism, 14(3), 191-207.

Blackbourn, J., McGarrity, N., \& Roach, K. (2019). Understanding and responding to right wing terrorism. Journal of policing, intelligence and counter terrorism, 14(3), 183190.

Blumer, H. (1958). Race prejudice as a sense of group position. Pacific Sociological Review, $1(1), 3-7$.

Braddock, K., \& Horgan, J. (2016). Towards a guide for constructing and disseminating counternarratives to reduce support for terrorism. Studies in Conflict \& Terrorism, 39(5), 381-404.

Braddock, K., \& Morrison, J. F. (2020). Cultivating trust and perceptions of source credibility in online counternarratives intended to reduce support for terrorism. Studies in Conflict \& Terrorism, 43(6), 468-492.

Breen-Smyth, M. (2014). Theorising the "suspect community": counterterrorism, security practices and the public imagination. Critical Studies on Terrorism, 7(2), 223-240.

Bull, M., \& Rane, H. (2019). Beyond faith: social marginalisation and the prevention of radicalisation among young Muslim Australians. Critical Studies on Terrorism, 12(2), 273-297.

Cherney, A., \& Murphy, K. (2016). Being a suspect community in a post 9/11 world: the impact of the War on terror on Muslim communities in Australia. Australian and New Zealand journal of criminology, 49(4), 480-496.

Chiricos, T., Welch, K., \& Gertz, M. (2004). Racial typification of crime and support for punitive measures. Criminology, 42(2), 358-390.

Crocker, D., Dobrowolsky, A., Keeble, E., Moncayo, C. C., \& Tastsoglou, E. (2007). Security and Immigration, Changes and Challenges: Immigrant and Ethnic Communities in Atlantic Canada, Presumed Guilty? https://www.researchgate.net/publication/265032032 Security and Immigration Ch anges_and_Challenges_Immigrant_and_Ethnic_Communities_in_Atlantic_Canada_P resumed_Guilty

Faist, T. (2002). 'Extension du domaine de la lutte': International Migration and Security before and after September 11, 2001. International Migration Review, 36(1), 7-14.

Finlay, K. A., \& Stephan, W. G. (2000). Improving intergroup relations: The effects of empathy on racial attitudes 1. Journal of Applied Social Psychology, 30(8), 17201737.

Graham-McLay, C. (2020). 'Our safety is a concern': fears endure among Muslims after Christchurch attacks. The Guardian. Retrieved from: 
https://www.theguardian.com/world/2020/mar/13/our-safety-is-a-concern-fearsendure-among-muslims-after-christchurch-attacks.

Huq, A., Tyler, T., and Schulhofer, S. (2011). Mechanisms for eliciting cooperation in counterterrorism policing: evidence from the United Kingdom. Journal of Empirical Legal studies, 8(4), 728-761.

Jacobs, D., \& Carmichael, J. T. (2002). The Political Sociology of the Death Penalty: A Pooled Time-Series Analysis. American Sociological Review, 67(1), 109-131.

Jonathan-Zamir, T., and Weisburd, D. (2013). The effects of security threats on Antecedents of police legitimacy: findings from a quasi-experiment in Israel. Journal of Research in Crime and Delinquency, 50(1), 3-32.

King, R. D., \& Wheelock, D. (2007). Group threat and social control: Race, perceptions of minorities and the desire to punish. Social Forces, 85(3), 1255-1280.

Lynch, A., McGarrity, N., \& Williams, G. (2015). Inside Australia's anti-terrorism laws and trials. NewSouth Publishing.

McGarrity, N., \& Blackbourn, J. (2019). Australia has enacted 82 anti-terror laws since 2001. But tough laws alone can't eliminate terrorism. The Conversation.

https://theconversation.com/australia-has-enacted-82-anti-terror-laws-since-2001-buttough-laws-alone-cant-eliminate-terrorism-123521.

Murphy, K., Madon, N. S., \& Cherney, A. (2020). Reporting threats of terrorism: stigmatisation, procedural justice and policing Muslims in Australia. Policing and society, 30(4), 361-377.

Nisbet, E. C., Ostman, R., \& Shanahan, J. (2008). Chapter 9: Public opinion toward Muslim Americans: Civil liberties and the role of religiosity, ideology, and media use. In A. H. Sinno (Ed.), Muslims in Western Politics (pp. 161-199). Indiana University Press.

Nolan, M. (2008). Lay perceptions of terrorist acts and counter-terrorism responses: Role of motive, offence construal, siege mentality and human rights. In M. Gani \& P. Mathew (Eds.), Fresh Perspectives on the "War on Terror". Canberra: ANU Press.

Piazza, J. A. (2015). Terrorist suspect religious identity and public support for harsh interrogation and detention practices. Political Psychology, 36(6), 667-690.

Powell, K. A. (2011). Framing Islam: An analysis of US media coverage of terrorism since 9/11. Communication Studies, 62(1), 90-112.

Reicher, S., \& Haslam, S. A. (2016). Fueling extremes. Scientific American Mind, 27(3), 3439.

Roach, K. (2011). The 9/11 Effect: Comparative Counter-terrorism. Cambridge University Press.

Robin-Olivier, S. (2005). Citizens and Noncitizens in Europe: European Union Measures Against Terrorism after September 11. Boston College Third World Law Journal, 25(1), 197-220.

Sentas, V. (2014). Traces of terror: Counter-terrorism law, policing, and race. Oxford University Press.

Spalek, B., \& Imtoual, A. (2007). Muslim communities and counter-terror responses: "Hard" approaches to community engagement in the UK and Australia. Journal of Muslim Minority Affairs, 27(2), 185-202.

Stephan, W. G., \& Finlay, K. (1999). The role of empathy in improving intergroup relations. Journal of Social issues, 55(4), 729-743.

Tingle, L. (2019). Scott Morrison said all the right things after Christchurch attack, but his history tells another story. ABC News. https://www.abc.net.au/news/2019-03-23/scottmorrison-end-of-tribalism-christchurch/10930682 
Unnever, J. D., \& Cullen, F. T. (2009). Empathetic Identification and Punitiveness: A Middle-Range Theory of Individual Differences. Theoretical Criminology, 13(3), 283-312.

Unnever, J. D., \& Cullen, F. T. (2010). Racial-Ethnic Intolerance and Support for Capital Punishment: A Cross-National Comparison. Criminology, 48(3), 831-864.

Unnever, J. D., \& Cullen, F. T. (2012). White perceptions of whether African Americans and Hispanics are prone to violence and support for the death penalty. Journal of Research in Crime and Delinquency, 49(4), 519-544.

Unnever, J. D., Cullen, F. T., \& Applegate, B. K. (2005). Turning the other cheek: Reassessing the impact of religion on punitive ideology. Justice Quarterly, 22(3), 304-339.

Unnever, J. D., Cullen, F. T., \& Fisher, B. S. (2005). Empathy and public support for capital punishment. Journal of Crime and Justice, 28(1), 1-34.

Unnever, J. D., Cullen, F. T., \& Jonson, C. L. (2008). Race, Racism, and Support for Capital Punishment. Crime and Justice, 37, 45-96.

Van de Vyver, J., Houston, D. M., Abrams, D., \& Vasiljevic, M. (2016). Boosting belligerence: How the July 7, 2005, London bombings affected liberals' moral foundations and prejudice. Psychological science, 27(2), 169-177.

van der Noll, J. (2010). Public support for a ban on headscarves: A cross-national perspective. . International Journal of Conflict and Violence, 4(2), 191-204.

Velasco González, K., Verkuyten, M., Weesie, J., \& Poppe, E. (2008). Prejudice towards Muslims in the Netherlands: Testing integrated threat theory. British Journal of Social Psychology, 47(4), 667-685.

Welch, K. (2016). Middle Eastern terrorist stereotypes and anti-terror policy support: The effect of perceived minority threat. Race and Justice, 6(2), 117-145.

Williams, G. (2011). A Decade of Australian Anti-Terror Laws. University of Melbourne Law Review, 35(3), 1136-1176.

Williamson, H. (2019). Pride and prejudice: Exploring how identity processes shape public attitudes towards Australian counter-terrorism measures. Australian \& New Zealand Journal of Criminology, 52(4), 558-577.

Williamson, H., Fay, S., \& Miles-Johnson, T. (2019). Fear of terrorism: media exposure and subjective fear of attack. Global Crime, 20(1), 1-25.

Williamson, H., Murphy, K., \& Sargeant, E. (2018). The Attitudes to Punishment Survey Technical Report. Brisbane: Griffith University.

Zammit, A. (2017). Australian Jihadism in the Age of the Islamic State. CTC Sentinel, 10(3), 23-30. 
Table 1. Sample demographics and representativeness against Australian census data

\begin{tabular}{|c|c|c|c|c|c|}
\hline \multirow[t]{2}{*}{ Demographic } & \multicolumn{2}{|c|}{$\begin{array}{c}\text { Wave 1 } \\
(\mathrm{n}=1,191)\end{array}$} & \multicolumn{2}{|c|}{$\begin{array}{c}\text { Wave } 2 \\
(n=1,344)\end{array}$} & \multirow{2}{*}{$\begin{array}{c}\text { Australian } \\
\text { population }^{\#} \\
\% \\
\end{array}$} \\
\hline & $\mathrm{N}$ & $\%$ & $\mathrm{~N}$ & $\%$ & \\
\hline Gender & & & & & \\
\hline Male & 510 & 42.8 & 667 & 50.0 & 49.3 \\
\hline Female & 681 & 57.2 & 668 & 50.0 & 50.7 \\
\hline \multicolumn{6}{|l|}{ Age $^{*}$} \\
\hline $15-19$ & 62 & 5.2 & 15 & 1.1 & 7.5 \\
\hline $20-24$ & 223 & 18.7 & 158 & 11.8 & 8.2 \\
\hline $25-34$ & 296 & 24.9 & 236 & 17.6 & 17.7 \\
\hline $35-44$ & 257 & 21.6 & 247 & 18.4 & 16.5 \\
\hline $45-54$ & 182 & 15.3 & 266 & 19.8 & 16.3 \\
\hline $55-64$ & 103 & 8.7 & 284 & 21.1 & 14.5 \\
\hline $65+$ & 67 & 5.6 & 138 & 10.3 & 16.8 \\
\hline \multicolumn{6}{|l|}{ Country of Birth } \\
\hline Australia & 1004 & 84.3 & 1100 & 81.8 & 73.7 \\
\hline Overseas & 187 & 15.7 & 244 & 18.2 & 26.3 \\
\hline \multicolumn{6}{|l|}{ Educational attainment } \\
\hline No education & 0 & 0.0 & 0 & 1.1 & 0.8 \\
\hline Did not complete high school & 96 & 8.1 & 139 & 9.4 & 23.7 \\
\hline Completed high school & 256 & 21.5 & 233 & 17.5 & 15.7 \\
\hline Trade/Technical Certificate/Diploma & 334 & 28.2 & 444 & 33.3 & 24.7 \\
\hline Bachelor's Degree or more & 498 & 42.0 & 516 & 38.8 & 22.0 \\
\hline \multicolumn{6}{|l|}{ State/Territory of Residence } \\
\hline NSW & 292 & 24.5 & 314 & 23.4 & 32.0 \\
\hline VIC & 217 & 18.2 & 269 & 20.0 & 25.7 \\
\hline QLD & 408 & 34.3 & 397 & 29.5 & 20.0 \\
\hline SA & 82 & 6.9 & 136 & 10.1 & 7.0 \\
\hline WA & 108 & 9.1 & 106 & 7.9 & 10.5 \\
\hline NT & 15 & 1.3 & 18 & 1.3 & 1.0 \\
\hline $\mathrm{ACT}$ & 33 & 2.8 & 49 & 3.6 & 1.7 \\
\hline TAS & 36 & 3.0 & 55 & 4.1 & 2.1 \\
\hline
\end{tabular}

* ABS proportions calculated without 0-14-year olds. \#Source: Australian Bureau of Statistics (2016). 
Table 2. Principal Components Analysis differentiating scale variables

\section{Perceptions that Muslims are Threatening}

Australian identity is being threatened because there are too many Muslims

Australian norms and values are being threatened because of the presence of Muslims

Muslims are a threat to Australia's way of life

Muslims are a threat to our safety

I do not trust Muslims

I am suspicious of Muslims

\section{Support for Punitive Counter-terrorism Policies}

Authorities should have the powers to question individuals on matters related to terrorism even if they are not

Authorities should be able to detain terrorist suspects without criminal charges for up to 48 hours

Authorities should be able to use stressful interrogation techniques to get confessions from suspected terrorists

Authorities should be able to conduct searches and seizures of the belongings of suspected terrorists without proper

Prison sentences for terrorists should be more severe than they currently are

$\%$ of variance

Extraction method: Principal Components analysis with varimax rotation. Factor loadings $>0.40$ are in boldface. 
Table 3. Descriptive statistics and bivariate correlations for all control variables and scales

\begin{tabular}{|c|c|c|c|c|c|c|c|c|c|c|c|c|c|c|c|}
\hline & $\begin{array}{c}\text { Item } \\
\mathrm{s}\end{array}$ & $\alpha$ & $M$ & $S D$ & $\%$ & 1 & 2 & 3 & 4 & 5 & 6 & 7 & 8 & 9 & 10 \\
\hline 1. Age & 1 & - & $\begin{array}{c}41 . \\
2\end{array}$ & $\begin{array}{c}15 . \\
2\end{array}$ & $\begin{array}{l}\mathrm{N} / \\
\mathrm{A}\end{array}$ & 1 & & & & & & & & & \\
\hline 2. Gender $(0=$ male $)$ & 1 & - & $\begin{array}{l}\mathrm{N} / \\
\mathrm{A}\end{array}$ & $\begin{array}{l}\mathrm{N} / \\
\mathrm{A}\end{array}$ & $\begin{array}{c}46 . \\
6\end{array}$ & $\begin{array}{c}- \\
230^{-} * * \\
*\end{array}$ & 1 & & & & & & & & \\
\hline $\begin{array}{l}\text { 3. Employment } \\
\text { status } \\
(0=\text { unemployed })\end{array}$ & 1 & - & $\begin{array}{l}\mathrm{N} / \\
\mathrm{A}\end{array}$ & $\begin{array}{l}\mathrm{N} / \\
\mathrm{A}\end{array}$ & $\begin{array}{c}43 . \\
0\end{array}$ & -0.027 & $-.040^{*}$ & 1 & & & & & & & \\
\hline $\begin{array}{l}\text { 4. Educational } \\
\text { attainment }\end{array}$ & 1 & - & 5.2 & 1.2 & $\begin{array}{l}\mathrm{N} / \\
\mathrm{A}\end{array}$ & $\begin{array}{c}.071 * * \\
*\end{array}$ & -0.004 & $\begin{array}{c}.265^{* *} \\
*\end{array}$ & 1 & & & & & & \\
\hline $\begin{array}{l}\text { 5. Political } \\
\text { orientation }\end{array}$ & 1 & - & 4.3 & 2.5 & $\begin{array}{l}\mathrm{N} / \\
\mathrm{A}\end{array}$ & $\begin{array}{c}.206^{* *} \\
*\end{array}$ & $\begin{array}{c}- \\
220^{* *} \\
*\end{array}$ & $.045^{*}$ & $\begin{array}{c}- \\
.082 * * \\
*\end{array}$ & 1 & & & & & \\
\hline $\begin{array}{l}\text { 6. Country of birth } \\
(0=\text { Australia })\end{array}$ & 1 & - & $\begin{array}{l}\mathrm{N} / \\
\mathrm{A}\end{array}$ & $\begin{array}{l}\mathrm{N} / \\
\mathrm{A}\end{array}$ & $\begin{array}{c}83 . \\
0\end{array}$ & $\begin{array}{c}.179 * * \\
*\end{array}$ & $\begin{array}{c}- \\
.077^{* *} \\
*\end{array}$ & -0.024 & $\begin{array}{c}- \\
.073^{* *} \\
*\end{array}$ & 0.034 & 1 & & & & \\
\hline $\begin{array}{l}\text { 7. Survey Time } \\
(0=\text { pre- } \\
\text { Christchurch })\end{array}$ & 1 & - & $\begin{array}{c}\mathrm{N} / \\
\mathrm{A}\end{array}$ & $\begin{array}{c}\mathrm{N} / \\
\mathrm{A}\end{array}$ & $\begin{array}{c}47 . \\
0\end{array}$ & $\begin{array}{c}.243 * * \\
*\end{array}$ & $\begin{array}{c}- \\
.071 * * \\
*\end{array}$ & 0.032 & -0.032 & $\begin{array}{l}.089^{* *} \\
*\end{array}$ & 0.033 & 1 & & & \\
\hline $\begin{array}{l}\text { 8. Vignette }(0=\mathrm{RW} \\
\text { extremist suspect })\end{array}$ & 1 & - & $\begin{array}{l}\mathrm{N} / \\
\mathrm{A}\end{array}$ & $\begin{array}{c}\mathrm{N} / \\
\mathrm{A}\end{array}$ & $\begin{array}{c}49 . \\
1\end{array}$ & 0.014 & -0.017 & -0.022 & -0.006 & $\begin{array}{c}.082 * * \\
*\end{array}$ & $.048 *$ & 0.004 & 1 & & \\
\hline $\begin{array}{l}\text { 9. Perceptions that } \\
\text { Muslims are } \\
\text { Threatening }\end{array}$ & 7 & $\begin{array}{c}0.9 \\
7\end{array}$ & 2.3 & 1.2 & $\begin{array}{l}\mathrm{N} / \\
\mathrm{A}\end{array}$ & $\begin{array}{c}.315^{* *} \\
*\end{array}$ & $\begin{array}{c}- \\
.205 * * \\
*\end{array}$ & -0.016 & $\begin{array}{c}- \\
.188 * * \\
*\end{array}$ & $\begin{array}{c}.573 * * \\
*\end{array}$ & 0.018 & $\begin{array}{c}.066^{* *} \\
*\end{array}$ & $\begin{array}{c}.096^{*} \\
*\end{array}$ & 1 & \\
\hline $\begin{array}{l}\text { 10. Support for } \\
\text { punitive counter- } \\
\text { terrorism policies }\end{array}$ & 9 & $\begin{array}{c}0.9 \\
0\end{array}$ & 3.1 & 1.0 & $\begin{array}{c}\mathrm{N} / \\
\mathrm{A}\end{array}$ & $\begin{array}{c}.178 * * \\
*\end{array}$ & $.053 * *$ & 0.007 & $\begin{array}{c}- \\
.200 * * \\
*\end{array}$ & $\begin{array}{c}.469 * * \\
*\end{array}$ & 0.029 & $\begin{array}{c}.062^{* *} \\
*\end{array}$ & $.052 *$ & $.575 * * *$ & 1 \\
\hline
\end{tabular}


Running head: Racial Animus and Support for Punitive Counter-terrorism Policies

Table 4. OLS Regression Predicting Support for Punitive Counter-terrorism Policies

\begin{tabular}{|c|c|c|c|c|c|c|c|c|}
\hline & \multicolumn{2}{|c|}{ Block 1} & \multicolumn{2}{|c|}{ Block 2} & \multicolumn{2}{|c|}{ Block 3} & \multicolumn{2}{|c|}{ Block 4} \\
\hline & $B(\mathrm{SE})$ & $\beta$ & $B(\mathrm{SE})$ & $\beta$ & $B(\mathrm{SE})$ & $\beta$ & $B(\mathrm{SE})$ & $\beta$ \\
\hline Constant & $2.983(.070)$ & $* * *$ & $3.382(.070)$ & $* * *$ & $2.965(.141)$ & $* * *$ & $2.99(.141)$ & $* * *$ \\
\hline $\begin{array}{l}\text { Vignette ( } 0=\mathrm{RW} \text { extremist } \\
\text { suspect) }\end{array}$ & $.104(.044)$ & $.052^{*}$ & $.022(.038)$ & 0.011 & $-.014(.034)$ & -0.007 & $-.015(.034)$ & -0.008 \\
\hline $\begin{array}{l}\text { Survey Time }(0=\text { pre- } \\
\text { Christchurch) }\end{array}$ & & & $-.003(.039)$ & -0.001 & $.029(.035)$ & 0.014 & $.026(.035)$ & 0.013 \\
\hline Age & & & $.01(.001)$ & $.151 * * *$ & $.003(.001)$ & $.053 * *$ & $.004(.001)$ & $.056^{* *}$ \\
\hline Gender $(0=$ female $)$ & & & $.353(.039)$ & $.178 * * *$ & $.389(.036)$ & $.196 * * *$ & $.39(.036)$ & $.196 * * *$ \\
\hline $\begin{array}{l}\text { Employment status } \\
(0=\text { unemployed })\end{array}$ & & & $.056(.040)$ & 0.028 & $.049(.036)$ & .024 & $.044(.036)$ & 0.022 \\
\hline Educational attainment & & & $-.147(.016)$ & $-.18 * * *$ & $-.082(.015)$ & $-.101 * * *$ & $-.083 .015)$ & $-.102 * * *$ \\
\hline $\begin{array}{l}\text { Country of birth }(0=\text { Australian } \\
\text { born })\end{array}$ & & & $-.108(.052)$ & $-.04 *$ & $-.074(.047)$ & -0.028 & $-.077(.047)$ & -0.029 \\
\hline Political orientation & & & $.187(.008)$ & $.465 * * *$ & $.095(.009)$ & $.237 * * *$ & $.096(.009)$ & $.239 * * *$ \\
\hline $\begin{array}{l}\text { Perceptions that Muslims are } \\
\text { Threatening }\end{array}$ & & & & & $.376(.019)$ & $.447 * * *$ & $.516(.049)$ & $.614 * * *$ \\
\hline $\begin{array}{l}\text { Survey Time } \mathrm{x} \text { Perceptions that } \\
\text { Muslims are Threatening }\end{array}$ & & & & & & & $-.091(.029)$ & $-.177 * *$ \\
\hline$R^{2}$ & .003 & & .29 & & .4 & & .4 & \\
\hline Adjusted $R^{2}$ & .002 & & .25 & & .4( & & .4 & \\
\hline$R^{2}$ Change & .003 & & .25 & & .1 & & .0 & \\
\hline$F$ Change & $5.457 *$ & & 115.90 & $* * *$ & 402.28 & $* * *$ & 9.74 & \\
\hline
\end{tabular}

\footnotetext{
* indicates a significant relationship at $\mathrm{p}<0.05 ; * *$ indicates a significant relationship at $\mathrm{p}<0.01 ; * * *$ indicates a significant relationship at $\mathrm{p}<0.001$.
} 
Running head: Racial Animus and Support for Punitive Counter-terrorism Policies

Figure 1. Participants' support for punitive counter-terrorism policies before and after the Christchurch attack as a function of vignette manipulation

\section{Support for Punitive Counter-terrorism Policies}

4

3.5

3
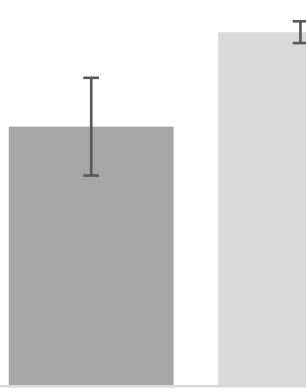

2.5

Pre-Christchurch Shootings
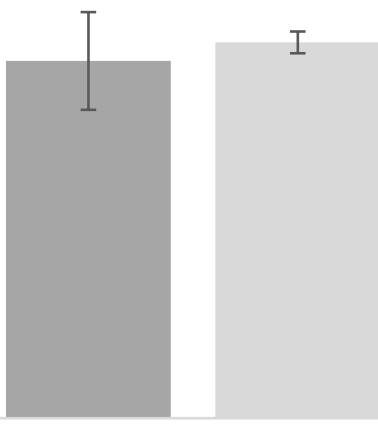

Post-Christchurch Shootings

$\square$ Right-wing extremist suspect $\square$ Islamist suspect 
Figure 2. Support for Punitive Counter-terrorism Policies as a function of Perceptions that Muslims are Threatening and Survey Time

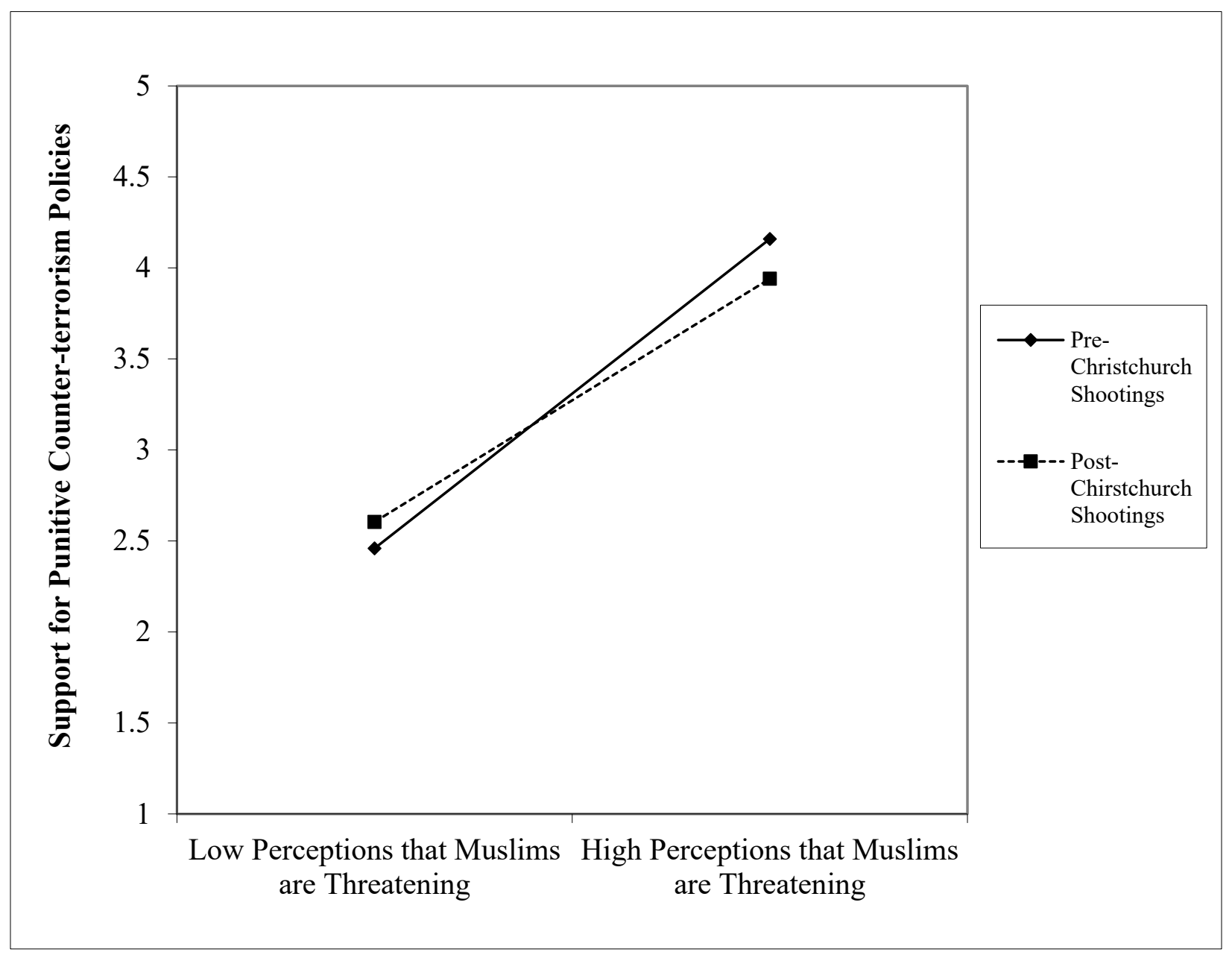




\section{Appendix \\ Vignette scenarios}

Police are investigating a possible food-tampering incident at a fast-food chain in Australia that has potential to put Australian consumers at harm. Authorities were alerted to the incident when several customers collapsed at four of the fast-food restaurants with undiagnosed conditions. Police have apprehended an individual suspected of carrying out this incident in Australia. In a Facebook post on a [Vignette A: radical Muslim page; Vignette B: right-wing extremist page], the suspect expressed their willingness to take such action in [Vignette A: the name of Allah; Vignette B: support of the anti-immigration movement (i.e., opposition to immigration into Australia]. All foodstuffs from the affected fast-food restaurants have been destroyed. Customers who have consumed food from these restaurants have been urged to seek medical advice immediately. This incident has resulted in high demand and long waiting periods in hospital emergency departments and consulting rooms of doctors around the country. People are reporting a range of symptoms to hospitals and doctors including severe stomach cramps, nausea, and vomiting. Emergency hotlines have been established to monitor the situation. Further details regarding the event are being withheld at this time. 